\section{Nauplius}

The Journal of The Brazilian Crustacean Society

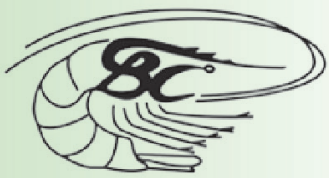

e-ISSN 2358-2936

www.scielo.br/nau www.crustacea.org.br

\title{
A review of the Leptostraca of the British Isles with discussion of the genus Sarsinebalia Dahl
}

\author{
Edward McCormack ${ }^{1}$, Christopher W. Ashelby ${ }^{2}$ \\ and David McGrath ${ }^{3}$ \\ 1 Aquafact International Services Ltd., 12, Kilkerrin Park, Liosbaun, Galway, Ireland. \\ (EMcC) E-mail: eddie@aquafact.ie
}

2 APEM Ltd., Diamond Centre, Works Road, Letchworth Garden City. SG6 1LW. United Kingdom. (CWA) E-mail: c.ashelby@apemltd.co.uk

3 Department of Life Sciences, Galway-Mayo Institute of Technology, Ireland.

(DMcG) E-mail: dave.mcgrath@gmit.ie

ZOOBANK http://zoobank.org/urn:lsid:zoobank.org:pub:5F395292-B1EB-4ED9B9B3-65F0A09AF166

\section{ABSTRACt}

A survey of the Leptostracan fauna of the British Isles collected from routine environmental monitoring samples revealed six species of Nebaliidae to be present in shallow waters. These species were identified as Nebalia herbstii Leach, 1814, Nebalia strausi Risso, 1826, Nebalia borealis Dahl, 1985, Nebalia kocatasi Moreira, Koçak and Katagan, 2007, Nebalia reboredae Moreira and Urgorri, 2009 in Moreira et al., 2009a and Sarsinebalia urgorrii Moreira, Gestoso and Troncoso, 2003. The presence of N. strausi, N. kocatasi, N. reboredae and S. urgorrii is reported from the British Isles for the first time. Three further species have been previously reported from the waters surrounding Britain and Ireland but were not recorded in the current study. Thus, the number of species recorded in the British Isles now stands at nine and the range of several species is extended northwards from previous records in the Mediterranean and the Iberian Peninsula. The diagnostic characters of Sarsinebalia Dahl, 1985 are discussed and it is suggested that a formal reappraisal of the genus be conducted. A key to European Leptostraca is provided based on adult females.

\section{KEY WORDS}

Nebaliidae, Ireland, United Kingdom, identification key, new records.

CORRESPONDING AUTHOR Edward McCormack eddie@aquafact.ie

SUBMITTED 17 February 2016 ACCEPTED 15 May 2016 PUBLISHED 14 July 2016

DOI 10.1590/2358-2936e2016006

\section{INTRODUCTION}

Leptostraca are the only extant members of the marine crustacean subclass Phyllocarida. They possess a movable rostrum, six pairs of pleopods, a pair of uropods and a bivalve carapace covering eight thoracopods. Leptostracans have long been documented from the British Isles and are known from 
shallow-and deep-water locations. However, the group is morphologically conservative and the traditionally used identifying characters were inadequate for species separation. Revisions of the group (Dahl, 1985; Moreira et al., 2003; 2007; 2009a; 2009b), including descriptions of several new species, have made it apparent that the list of species reported from the British Isles is inaccurate and the distribution of the previously reported species must be re-evaluated.

Mauchline (1984) lists four species of Leptostraca within the fauna of the British Isles. These include Nebalia bipes (Fabricius, 1780), Sarsinebalia typhlops (G.O. Sars, 1870), Nebaliella caboti Clark, 1932 and Nebaliopsis typica G.O. Sars, 1887. Nebalia bipes has historically been widely recorded from British and Irish coasts. Tattersall (1911) recorded it from the Clare Island Survey "at low water at spring tides, under stones and seems to prefer the neighbourhood of black, evil-smelling mud”. Fahy (1985) recorded it from the gut contents of sea trout from Mulroy Bay, Co. Donegal. Dahl (1985) provided a revision of the European Leptostraca and demonstrated that N. bipes is not a cosmopolitan species recorded throughout western European coastal waters but instead is a boreal, circum-Arctic species known only from Greenland, Arctic North America, and Svalbard to western Norway. Considering Dahl's (1985) revised distribution of $N$. bipes and his statement that Nebalia herbstii Leach, 1814 was the commonest species of Nebalia Leach, 1814 of the British Isles and the western coast of France, O'Reilly et al. (2001) suggested that it seems probable that most of the British records of $N$. bipes should refer to N. herbstii. Correspondingly, it should be considered that all historical identifications of $N$. bipes from the British Isles should be seen as suspect and should be re-examined.

In addition to N. bipes, historical records of British and Irish Nebaliidae include N. herbstii, Nebalia borealis Dahl, 1985, Nebalia strausi Risso, 1826 and Sarsinebalia typhlops, Nebaliella caboti and Nebaliopsis typica. Sarsinebalia typhlops has previously been recorded (as Nebalia typhlops) by Tattersall (1905) off the west coast of Ireland: 60 miles west of Achill Head in $364 \mathrm{~m}$ of water and 50 miles off Cleggan Head, Co. Galway in 220 m of water. Linder (1943) recorded N. typica from the extreme south-west of the continental slope. Mauchline and Gage (1983) also recorded S. typhlops (as Nebalia typhlops), N. caboti and N. typica at $>1500 \mathrm{~m}$ from the Rockall Trough. Nebalia herbstii is previously recorded from the south-west and western coast of England (Leach, 1814; Dahl, 1985), the Channel Islands, Dublin Bay in the gut of Gaidropsarus mediterraneus (Linnaeus, 1758) and off SW Ireland, location not specified (Dahl, 1985). British records of N. strausi are confined to the Channel Islands (Dahl, 1985) whilst $N$. borealis has only been reported from Shetland (Dahl, 1985).

The current study examines recent collections of Nebaliidae from inshore and offshore waters around the Irish and British coasts, providing further records for some of the previously known species and demonstrating the occurrence of additional species in these waters.

\section{Material and Methods}

Specimens of Nebaliidae were collected from numerous locations during surveys of inshore and offshore waters around the British Isles. The surveys included benthic surveys of Marine Natura 2000 sites, benthic audits of marine fish farms, ecological surveys related to marine aggregate extraction and the oil and gas industry and the U.K.'s Marine Conservation Zone programme. Macrofaunal samples were collected using $0.1 \mathrm{~m}^{2}$ Day grabs, $0.1 \mathrm{~m}^{2}$ mini-Hamon grabs, dredges and diver-operated cores but did not deliberately target leptostracans. During these surveys macrofaunal samples were fixed in $10 \%$ buffered formalin, sieved over either a 0.5 or a $1.0 \mathrm{~mm}$ mesh and the residues were sorted under either a Nikon SMZ-10 or Nikon SMZ-645 stereomicroscope into various taxa and transferred to $70 \%$ ethanol prior to identification. The leptostracan material was subsequently re-analysed for the current study. All specimens were compared against published descriptions of the species with all diagnostic characters carefully considered. Where available, accompanying habitat and collection data have been included in the material examined; however, since some of the macrofaunal samples were provided by third-party contractors these data have not always been made available. Where grain size analysis was carried out the substrate classification is based on that of Folk (1954). Where this analysis was not carried out the substrate descriptions were based on visual examination of the sediment in the field. In total, 
1,251 leptostracan specimens were examined. Sex of a proportion of the material was determined using the relative length of the antennae to the body to provide an indication of the proportion of males to females but this was not conducted for all lots. Voucher specimens have been deposited in the zoological collections of the National Museum of Ireland - Natural History (NMINH) and Oxford University Museum of Natural History (OUMNH.ZC). Specimens that had previously been cited by O'Reilly et al. (2001) are housed at SEPA. Irish specimens examined by Juan Moreira, (JM), Universidad Autónoma de Madrid, are retained in his collection. The remaining leptostracan specimens are retained in the collections of the authors (Irish material with Aquafact International Services Ltd. and U.K. material with APEM Ltd.). Line drawings were made using a camera lucida connected to a Nikon YS2-B microscope. Maps are presented for each species discussed. For Sarsinebalia typhlops, Nebaliella caboti and Nebaliopsis typica these are based on the records presented by Tattersall (1905) and Mauchline and Gage (1983) since no material was available to us. For all other species, maps are based only on material reviewed in the present study, given the likelihood of previous misidentifications. Various records of Leptostraca from online datasets and grey literature have not been referenced as confirmation of identifications could not be established.

ResULTS

\section{Family Nebaliidae Samouelle, 1819}

\section{Genus Nebalia Leach, 1814}

\section{Nebalia strausi Risso, 1826}

Material examined. Ireland. $1 \hat{\bigcirc}, 3 \bigcirc$, Kilkieran Bay, Co. Galway, $53^{\circ} 19.548^{\prime} \mathrm{N} 009^{\circ} 38.9165^{\prime} \mathrm{W}, 7.9 \mathrm{~m}$, sandy gravel, 15.x.2010.4^, 4ㅇ, Kingstown Bay, Co. Galway, $53^{\circ} 30.905^{\prime} \mathrm{N} 10^{\circ} 7.6979$ 'W, $10 \mathrm{~m}$, gravelly muddy sand, 16.x.2010.3ㅇ, Valentia Island, Co. Kerry, $51^{\circ} 53.819^{\prime} \mathrm{N}$ $10^{\circ} 18.786^{\prime} \mathrm{W}, 4 \mathrm{~m}$, muddy sandy gravel, 16.ix.2010 (NMINH:2016.1.5, 1q). 1 q, Valentia Island, Co. Kerry, 51 ${ }^{\circ} 53.2439^{\prime} \mathrm{N} 10^{\circ} 21.948^{\prime} \mathrm{W}, 6$ m, maërl, 16.ix.2010 (NMINH:2016.1.4, 1) ). $1 \jmath^{\lambda}, 5$, Ahabeg,
Bantry Bay, Co. Cork, at edge of stocked salmon farm cage located at $51^{\circ} 39.7302^{\prime} \mathrm{N} 009^{\circ} 45.1727^{\prime} \mathrm{W}, 20-23.4$ m, mud with broken shell, 4.ix.2012 (JM:2014, 1ð, 4 ㅇ) $.1 \delta^{\wedge}$ adult, Glinsk, Mulroy Bay, Co. Donegal, $55^{\circ} 12.1368^{\prime} \mathrm{N} 007^{\circ} 47.0682^{\prime} \mathrm{W}, 8-15 \mathrm{~m}$, medium sand with both live and dead maërl, 14.viii.2012. $1 \sigma^{\lambda}$ adult, Millstone, Mulroy Bay, Co. Donegal, $50 \mathrm{~m}$ from stocked salmon farm, $55^{\circ} 11.4205^{\prime} \mathrm{N} 007^{\circ} 45.388^{\prime} \mathrm{W}$, 5-12.9 m, medium sand with maërl gravel, 15.viii.2012 (JM:2014, 1ठ).

British and Irish Distribution. South-west, west, and north of Ireland (Co. Cork, Co. Kerry, Co. Galway and Co. Donegal) and Guernsey (Dahl, 1985) (Fig. 1A).

Distribution beyond the study area. Gulf of Naples, Italy (type locality), Eastern Atlantic, from the northwest coast of France to St. Helena (Dahl, 1985). Western Mediterranean (Dahl, 1985). Eastern Mediterranean (Koçak and Katagan, 2006; Koçak et al., 2007). Concarneau, Brittany, France (J.M.C. Holmes, pers. comm.).

Ecology. Coarse sediments, from gravel to coarse sand at depths of 12.7-15.2 m, Total Organic Matter (\%TOM) 0.6-4.9 (Moreira et al., 2009a). Maërl, medium sand to mud at depths of 4-23.4 m, \%TOM 2.92-18.93 (present study).

Remarks. Nebalia strausi is recorded for the first time from Irish waters. Records of N. strausi to date suggest a southerly distribution with the specimens from Mulroy Bay, Co. Donegal, representing the northernmost extent of its range. Features distinguishing N. strausi from other species of Nebalia within the North-East Atlantic include distally acute denticles on the posterior margin of pleonites 6 and 7, in conjunction with an antennular flagellum with more than 10 articles and the exopod of the 2 nd maxilla barely extending past the proximal article of the endopod. However, research (Moreira et al., 2004; Koçak et al., 2010) has shown that specimens of $N$. strausi from different localities can exhibit variation in a number of characters including the shape of the anal scales and the denticles of the posterior border of pleonites 6-7. Koçak et al. (2011) suggested that the existence of cryptic species cannot be ruled out for $N$. strausi. 

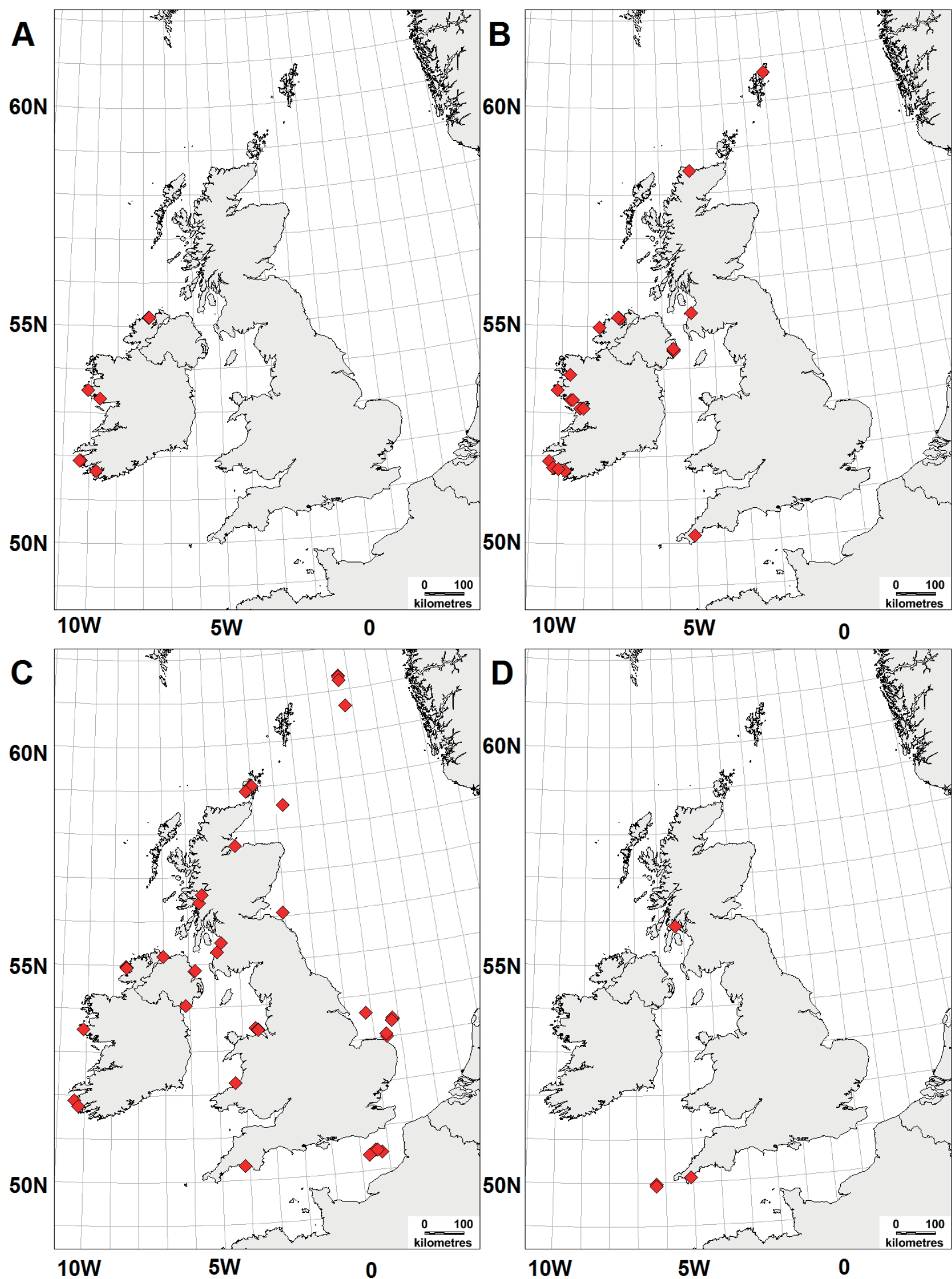

Figure 1. Distribution of Leptostraca in the British Isles: (A) Nebalia strausi Risso, 1826; (B) Nebalia kocatasi Moreira, Koçak and Katagan, 2007; (C) Nebalia reboredae Moreira and Urgorri, 2009 in Moreira et al., 2009a; (D) Nebalia herbstii Leach, 1814. 
Nebalia kocatasi Moreira, Koçak and Katagan, 2007

Material examined. Ireland. $40 \bigcirc, 16 \bigcirc^{\lambda}, 52$ juveniles, Finavarra, Co. Clare, 53⒐270’N 009 $7.059^{\prime} \mathrm{W}$, intertidal, semi-exposed shingle, stone and sand beach, 18.ix.2009 (NMINH:2016.1.1, 3 $\hat{\jmath}, 5$ + $) .5$, $10^{\lambda}$, Corranroo, Co. Clare, $53^{\circ} 9.033^{\prime} \mathrm{N} 009^{\circ} 0.509^{\prime} \mathrm{W}$, intertidal sheltered rocky shore with a muddy substrate, 10.x.2009. 3 우, 22 이, $10 \bigcirc^{\lambda}, 19$ juveniles, Carna, Co. Galway, 53¹8.712’N 00951.535’W, intertidal, exposed rocky shore with a sandy substrate, 21.ix.2009. 1 , Aran Island, Co. Donegal, $54^{\circ} 58.2359^{\prime} \mathrm{N} 008^{\circ} 31.0488^{\prime} \mathrm{W}, 5.7 \mathrm{~m}$, sandy gravel, 1.ix.2010. 7 + $, 3{ }^{\top}, 17$ juveniles, Kilkieran Bay, Co. Galway, 53⒘508’N 009³6.3858’W, 4 m, gravelly muddy sand, 17.x.2010. 22 $\hat{\jmath}, 132 \uparrow, 43$ juveniles, Kingstown Bay, Co. Galway, 53³0.905’N 107.6979’W, $10 \mathrm{~m}$, gravelly muddy sand, 16.x.2010.6 $\hat{\jmath}, 2$ ㅇ, 30 juveniles, Kingstown Bay, Co. Galway, 5330.93’N $10^{\circ} 7.8359^{\prime} \mathrm{W}, 6 \mathrm{~m}$, muddy sandy gravel, 16.x.2010.4ㅇ, Valentia Island, Co. Kerry, 51 $53.418^{\prime} \mathrm{N} 10^{\circ} 21.5879^{\prime} \mathrm{W}$, $5 \mathrm{~m}$, muddy sandy gravel, 16.ix.2010.1일 Valentia Island, Co. Kerry, 51 $53.2439^{\prime} \mathrm{N} 10^{\circ} 21.948^{\prime} \mathrm{W}, 6 \mathrm{~m}$, maërl, 16.ix.2010. $3{ }^{\Uparrow}, 18$, 28 juveniles, Deenish, Kenmare Bay, Co. Cork, at the edge of a stocked salmon farm located at $51^{\circ} 44.364^{\prime} \mathrm{N} 10^{\circ} 12.8189^{\prime} \mathrm{W}$, $23.2 \mathrm{~m}$, medium sand with mussel shell, signs of low oxygen/organic enrichment (Beggiatoa spp. patches), 13.ix.2012 (NMINH:2016.1.2, 3ðे, 1 , , 4 juveniles;

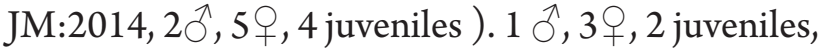
Inishfanard, Kenmare Bay, Co. Cork, at the edge of a stocked salmon farm at $51^{\circ} 42.702^{\prime} \mathrm{N} 10^{\circ} 0.4408^{\prime} \mathrm{W}, 20$ $23 \mathrm{~m}$, muddy sand with shell debris, signs of signs of low oxygen/organic enrichment (Beggiatoa spp. patches),

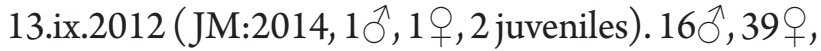
59 juveniles, Ahabeg, Bantry Bay Co. Cork, at edge of stocked salmon farm cage located at $51^{\circ} 39.7302^{\prime} \mathrm{N}$ $009^{\circ} 45.1727^{\prime} \mathrm{W}, 20-23.4 \mathrm{~m}$, mud with shell fragments,

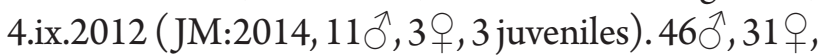
34 juveniles, Inishdoonver, Clew Bay, Co. Mayo, at edge of a stocked salmon farm, $53^{\circ} 52.7711^{\prime} \mathrm{N} 009^{\circ} 39.052^{\prime} \mathrm{W}$, $21.7 \mathrm{~m}$, cobbles with shell and stone gravel and patches of sand, 20.vii.2012 (JM:2014, 45 $\lesssim, 30$, 31 juveniles). $6 \AA$, 10 , 16 juveniles, Glinsk, Mulroy Bay, Co. Donegal, at edge of a stocked salmon farm located at $55^{\circ} 12.0912^{\prime} \mathrm{N} 007^{\circ} 46.9314^{\prime} \mathrm{W}, 8-13.1 \mathrm{~m}$, medium sand with shell gravel, signs of signs of low oxygen/organic enrichment (small patches of Beggiatoa spp.), 14.viii.2013 (JM:2014, $2 \hat{\jmath}, 4$,, 3 juveniles). 1 , Glinsk, Mulroy Bay, Co. Donegal, $150 \mathrm{~m}$ from edge of stocked salmon farm, $55^{\circ} 12.1368^{\prime} \mathrm{N} 007^{\circ} 47.06819^{\prime} \mathrm{W}$, 8-13.1 m, medium sand with live and dead maërl and shell debris, 14.viii.2013 (JM:2014, 19). 10ㅇ, 6 juveniles, Millstone, Mulroy Bay, Co. Donegal, at the edge of a stocked salmon farm, $55^{\circ} 11.446^{\prime} \mathrm{N}$ $007^{\circ} 45.4068^{\prime} \mathrm{W}, 5-12.9 \mathrm{~m}$, medium sand with a shell gravel fraction and maërl debris, 15.viii.2012 (JM:2014, 19 ). $4 \delta^{\top}, 7 \bigcirc$, Cranford, Mulroy Bay, Co. Donegal, near edge of a stocked salmon farm, $55^{\circ} 10.4491^{\prime} \mathrm{N}$ $007^{\circ} 42.1786^{\prime} \mathrm{W}, 5-12.9 \mathrm{~m}$, fine/medium sand with silt and shell debris, sparse patches of bacterial mats (Beggiatoa spp.) and feed from salmon farm, 14.viii.2012 ( JM:2014, $2 \hat{\bigcirc}, 2 \bigcirc$ ). Northern Ireland. 2 specimens, Strangford Lough, 54²7.000'N 005³6.000'W, $19.7 \mathrm{~m}$, mud with shell, 30.v.2012. 1 specimen, Strangford Lough, 54²5.000'N 005³7.480'W, 17.1 m, shelly mud, 30.v.2012 (OUMNH.ZC.2016-01008, 1 specimen). 2 specimens, Strangford Lough, $54^{\circ} 24.500^{\prime} \mathrm{N} 005^{\circ} 35.400^{\prime} \mathrm{W}, 60.1 \mathrm{~m}$, muddy sand with shell, 31.v.2012. 1 specimen, Strangford Lough, $54^{\circ} 27.730^{\prime} \mathrm{N} 005^{\circ} 36.640^{\prime} \mathrm{W}, 18.8 \mathrm{~m}$, mud with shell, 18.vi.2013. England. 1 specimen, Falmouth, Cornwall, 50 93.770’ $\mathrm{N} 005^{\circ} 39.100^{\prime} \mathrm{W}, 4.4 \mathrm{~m}$, clean broken shells/ maërl, 01.v.2013. Scotland. 9 specimens, Sian Bay, Loch Eriboll, Highlands, $58^{\circ} 31.325^{\prime} \mathrm{N} 004^{\circ} 40.011^{\prime} \mathrm{W}, 20.1$ $\mathrm{m}$, sand with shell, 05.xi.2010 (OUMNH.ZC.2016-01007, 9 specimens). 2 specimens, Sian Bay, Loch Eriboll, Highlands, 58 $31.325^{\prime} \mathrm{N} 004^{\circ} 40.011^{\prime} \mathrm{W}, 20.1 \mathrm{~m}$, sand with shell, 05.xi.2010. 1 specimen, south-west Scotland, $55^{\circ} 15.901^{\prime} \mathrm{N} 004^{\circ} 51.197^{\prime} \mathrm{W}, 1.9 \mathrm{~m}$, poorly sorted very coarse sand, 11.vii.2015. 5 specimens, south-west Scotland, $55^{\circ} 16.139^{\prime} \mathrm{N} 004^{\circ} 51.483^{\prime} \mathrm{W}, 11.6 \mathrm{~m}$, poorly sorted very fine gravel, 11.vii.2015. 5 specimens, North Sandwick, Yell, Shetland, $60^{\circ} 39.122^{\prime} \mathrm{N} 000^{\circ} 59.450^{\prime} \mathrm{W}$, $15 \mathrm{~m}, 2003$.

British and Irish Distribution. North, west and southwest of Ireland (Co. Donegal, Co. Mayo, Co. Galway, Co. Kerry, Co. Cork), Cornwall, western and northern Scotland, Shetland (Fig. 1B).

Distribution beyond the study area. Izmir Bay, Turkey (type locality). Cyprus and the Aegean Sea to the western Iberian Peninsula and the Canary Islands 
(Moreira et al., 2007; Koçak et al., 2011). Based on the previously known distribution and the present records it seems likely that this species is also present along the west coast of France and southern North Sea coasts but this requires confirmation.

Ecology. Gravel to fine sand with mats of Zostera marina, at depths of 4.5-13.8 m, \%TOM 1.2-4.9 (Moreira et al., 2009a). Cobbles and gravel to mud, at depths of 4-23.2 m, \%TOM 0.69-18.93 (present study). Intertidal on semi-exposed and sheltered rocky shores. The study of their distribution relative to aquaculture cages indicates that this species is most abundant at the edges of the cages as distinct from directly beneath them or further out.

Remarks. The specimens examined agree closely with the description and figures given by Moreira et al. (2007). A comparison of diagnostic characters of Mediterranean species of Nebalia by Koçak and Moreira (2015) highlights useful differences between $N$. kocatasi and other species, in particular the lateral armature of the 3rd article of the antenna (N. kocatasi has 3 thin setae and 3 spine-like setae with the proximal spine-like seta smallest (Fig. 5A). Nebalia kocatasi is the only species that has been recorded in this study from the intertidal zone. This likely reflects the sampling methodology rather than true habitat preferences. Numerous specimens of $N$. kocatasi from Kenmare, Co. Kerry, and Finavarra, Co. Clare as well as two specimens from Shetland, had epibionts on the pleonites and on the carapace (Fig. 6). These had a total length of 306 392 $\mu \mathrm{m}$, capsule length of 219 274 $\mu \mathrm{m}$ and stalk length of 86 141 $\mu \mathrm{m}(\mathrm{n}=15)$. A study of these by Gregorio FernandezLeborans (Universidad Complutense, Madrid) could not determine their identity but concluded they were most likely protozoans. Over 40 species of chonotrich ciliates are known from Nebaliaceans (FernandezLeborans, 2001).

\section{Nebalia reboredae Moreira and Urgorri, 2009 in Moreira et al., 2009a}

Material examined. Ireland. 29 , Deenish, Kenmare Bay, Co. Kerry, 5144.364’N 10¹2.8189’W, 23.2 m, on medium sand with shell gravel, 13.ix.2012 (NMINH:2016.1.3, 2q). $3 \hat{\jmath}, 1+$, Aran Island, Co. Donegal, 54 58.2359’ N 008 31.0488’ W, $5.7 \mathrm{~m}$, sandy gravel, 1.ix.2010.2 9 , 1 juvenile, Sound of Aran, Co. Donegal, 5457.4439'N 008²8.6248'W, 5.5 m, gravelly sand, 1.ix.2010.3 1 , 1 juvenile, Sound of Aran, $54^{\circ} 56.562^{\prime} \mathrm{N} 008^{\circ} 28.2629^{\prime} \mathrm{W}, 9.9 \mathrm{~m}$, gravelly sand, 1 September 2010. 12 specimens, Lough Foyle, Co. Donegal, $55^{\circ} 11.510^{\prime} \mathrm{N} 007^{\circ} 00.765^{\prime} \mathrm{W}, 9.5 \mathrm{~m}$, sand with shell, 29.iii.2012. 1 specimen, Lough Foyle, Co. Donegal, $55^{\circ} 11.510^{\prime} \mathrm{N} 007^{\circ} 00.765^{\prime} \mathrm{W}, 15.6 \mathrm{~m}$, sand with shell, 26.vi.2013. 2 juveniles, Kingstown Bay, Co. Galway, 53³0.9829’N 108.22’W, 9.3 m, gravelly sand, 16.x.2010.3 , Valentia Island, Co. Kerry, $51^{\circ} 52.5599^{\prime} \mathrm{N} 10^{\circ} 24.444^{\prime} \mathrm{W}, 40 \mathrm{~m}$, gravelly sand.

Northern Ireland. 19 , NE of Skernaghan Pt, Larne, Co. Antrim, dredge, $54^{\circ} 51.6869^{\prime} \mathrm{N} 005^{\circ} 45.384^{\prime} \mathrm{W}, 25$ $\mathrm{m}$, gravel and shell, 15.iv.2010. 5 specimens, Larne Lough, 54 $50.352^{\prime} \mathrm{N} 005^{\circ} 47.802^{\prime} \mathrm{W}, 5.7 \mathrm{~m}$, muddy sand, 14.iii.2013. 2 specimens, Carlingford Lough, $54^{\circ} 03.271^{\prime} \mathrm{N} 006^{\circ} 09.058^{\prime} \mathrm{W}, 7 \mathrm{~m}$, muddy sand with shell, 05.vii.2013. Scotland. 1 specimen, Oban Bay, 56 24.862'N 005²9.708' W, 37.6 m, gravelly shelly mud, 09.xii.2010. 19 specimens, Kirkwall Bay, 5902.014'N 002 59.722'W, 13 m, 25.v.2014. 2 specimens, Kirkwall Bay, 5901.281'N 002 58.329'W, $12 \mathrm{~m}, 25 . v .2014 .1$ specimen, St. Abbs, 5604.500’ N $002^{\circ} 05.460$ 'W, 55 m, $02 . v i .1986$ [specimen previously cited by O'Reilly et al. (2001) as N. herbstii]. 1 specimen, Ayr Bay, 55²8.570’N 00241.000’W, 17 m, 08.ix.1989. 1 specimen, Shuna Island, Loch Linnhe, $56^{\circ} 35.570^{\prime} \mathrm{N} 005^{\circ} 22.750^{\prime} \mathrm{W}, 01 . v i .1992 .1$ specimen, Bring Head, Hoy, Orkney, 58 54.050’N 003⒗191’W, $20 \mathrm{~m}$, sand, 17.x11.2012. 1 specimen, St. Margaret's Hope, Orkney, 15.v.2015. 1 specimen, south-west Scotland, $55^{\circ} 16.121^{\prime} \mathrm{N} 004^{\circ} 51.617^{\prime} \mathrm{W}, 10.6 \mathrm{~m}$, poorly sorted coarse sand, 11.vii.2015. 3 specimens, Moray Firth (Hilton of Cadboll Water Body), 57 $38.09^{\prime} \mathrm{N}$ 00357.49' W, 19 m, 23.vi.2015. Wales. 1 specimen, Cardigan Bay, 52 $15.054^{\prime} \mathrm{N} 004^{\circ} 22.582^{\prime} \mathrm{W}, 21.7 \mathrm{~m}$, 2.vii.2014. England. 1 specimen, Plymouth Sound, $50^{\circ} 19.933^{\prime} \mathrm{N} 004^{\circ} 09.200^{\prime} \mathrm{W}, 9.6 \mathrm{~m}$, coarse sand, 30.iii.2011. 1 specimen, eastern English Channel, $50^{\circ} 27.845^{\prime} \mathrm{N} 000^{\circ} 32.794$ 'E, $43.7 \mathrm{~m}$, sandy gravel, 2.viii.2014. 1 specimen, eastern English Channel, $50^{\circ} 23.765^{\prime} \mathrm{N} 000^{\circ} 45.489^{\prime} \mathrm{E}, 39.8 \mathrm{~m}$, sandy gravel, 
1.viii.2014. 1 specimen, eastern English Channel, $50^{\circ} 26.977^{\prime} \mathrm{N} 000^{\circ} 36.590^{\prime} \mathrm{E}, 46.8 \mathrm{~m}$, gravelly sand, 2.x.2014. 1 specimen, eastern English Channel, $50^{\circ} 21.401^{\prime} \mathrm{N} 000^{\circ} 18.366^{\prime} \mathrm{E}, 43.9 \mathrm{~m}$, sandy gravel, 30.vii.2014. 1 specimen, Cromer Shoals, 52 $59.807^{\prime} \mathrm{N}$ 001 28.649'E, $11.6 \mathrm{~m}$, sand, 12.ix.2014. 1 specimen, Cromer Shoals, 5304.062’N 001²7.237’E, $10.7 \mathrm{~m}$, mixed sediments, 12.ix.2014. 1 specimen, Liverpool Bay, $53^{\circ} 29.165^{\prime} \mathrm{N} 003^{\circ} 30.429^{\prime} \mathrm{W}, 21.9 \mathrm{~m}$, gravelly sand, 29.x.2014. 2 specimens, Liverpool Bay, 5326.970’ $\mathrm{N}$ $003^{\circ} 23.971^{\prime} \mathrm{W}, 16.0 \mathrm{~m}$, gravelly sand, 30.x.2014. 4 specimens, Liverpool Bay, 5326.038’N 003²4.593’W, $13.8 \mathrm{~m}$, sandy gravel, 30.x.2014. North Sea. 5 specimens, Osprey Field, 61 ${ }^{\circ} 19.530^{\prime} \mathrm{N} 004^{\circ} 32.601^{\prime} \mathrm{E}$, 159.9 m, muddy sand, 6.xii.2008. 1 specimen, Dunlin Field, $61^{\circ} 18.115^{\prime} \mathrm{N} 001^{\circ} 32.060^{\prime} \mathrm{E}, 155 \mathrm{~m}$, muddy sand, 11.xi.2009. 1 specimen, Dunlin Field, $61^{\circ} 13.141^{\prime} \mathrm{N}$ 001 $30.927^{\prime} \mathrm{E}, 148.1 \mathrm{~m}$, muddy sand, 08.xi.2009. 2 specimens, Clipper Field, 5323.826’N 001 47.205’E, $25.1 \mathrm{~m}$, sandy gravel, 27.xii.2008. 2 specimens, Clipper Field, $53^{\circ} 24.179^{\prime} \mathrm{N} 001^{\circ} 46.431$ 'E, 24 . m, sandy gravel, 27.xii.2008 (OUMNH.ZC.2016-01-009, 2 specimens). 2 specimens, Dunbar Field, 60³7.700’N 001³9.200’E, 145 m. 6 specimens, Clipper Field, 5321.452’N $001^{\circ} 44.148^{\prime} \mathrm{E}, 29.9 \mathrm{~m}$, muddy sand, 2.ii.2009. 1 specimen, Juliet Field, 5335.444’N 00046.261'E, $33.3 \mathrm{~m}$, sandy gravel, 10.ix.2009.

British and Irish Distribution. West and north-west of Ireland (Co. Kerry, Co. Galway, Co. Donegal) and east of Northern Ireland (Co. Antrim) (Fig. 1C).

Distribution beyond the study area. Ría de Ferrol, Galicia, Spain (type locality). Based on the previously known distribution and the present records it seems likely that this species is also present along the west coast of France and continental southern North Sea coasts but this requires confirmation.

Ecology. Medium sand at depth of $6.4 \mathrm{~m}, 1.4 \%$ TOM (Moreira et al., 2009a). Gravelly sand at depths of 5.5-40 m, 0.69-3.1\% TOM (present study). Nebalia reboredae appears to be the European species of Nebalia which shows a greater affinity for sandy sediments.

Remarks. The specimens examined agree closely with the description and figures given by Moreira et al. (2009a). Contrary to Dahl's statement that Nebalia herbstii is the dominant Nebalia species in British waters, $N$. reboredae was the most commonly recorded in this study.

\section{Nebalia herbstii Leach, 1814}

Material examined. Scotland. 16 specimens, Rubha Stillaig, Loch Fyne, Stn 17:2, 5551.860’N 005 18.900'W, 08.vi.1999. England. 1 specimen, Falmouth, Cornwall, 5054.740'N 005 54.910'W, 6.8 $\mathrm{m}$, clean shells/maërl, 2.v.2013. 9 specimens, northeast Isles of Scilly, 49 55.289'N 006 $19.926^{\prime}$ W, 15.9 $\mathrm{m}$, sand, 26.v.2013. 110 specimens, north-east Isles of Scilly, $49^{\circ} 58.125^{\prime} \mathrm{N} 006^{\circ} 19.257^{\prime} \mathrm{W}, 6.1 \mathrm{~m}$, coarse (3-4 cm) gravel with mud and abundant macroalgae, 27.v.2013.

British and Irish Distribution. Shetland, western British Isles (Dahl, 1985), south-west and western coasts of England (Leach, 1814), Loch Fyne, Isles of Scilly, Falmouth (present study) (Fig. 1D).

Distribution beyond the study area. Western France to Spanish border (Walker-Smith and Poore, 2001); northern coast of the Iberian Peninsula (Martínez et al., 2007).

Ecology. Shallow (6.1-15.9 m), near-shore waters over sands, muds, gravels and maërl (present study). Occurring under stones that lay on mud amongst the hollows of the rocks (Leach, 1814).

Remarks. Dahl (1985) believed N. herbstii to be the dominant species of the genus in the British Isles. For this reason, many subsequent records of Nebalia from the British Isles have been attributed to $N$. herbstii. The material examined in the present study demonstrates that far from being the most common species of the genus it is relatively uncommon, in routine samples at least. Dahl (1985) also believed that the species may well occur around the Iberian Peninsula; however, Moreira et al. (2009a) could not confirm the occurrence of $N$. herbstii there. Ledoyer (1997) recorded its presence in the Mediterranean (Corsica and Bonnieu, France). However, Koçak et al. (2011) suspect that these specimens may refer to 

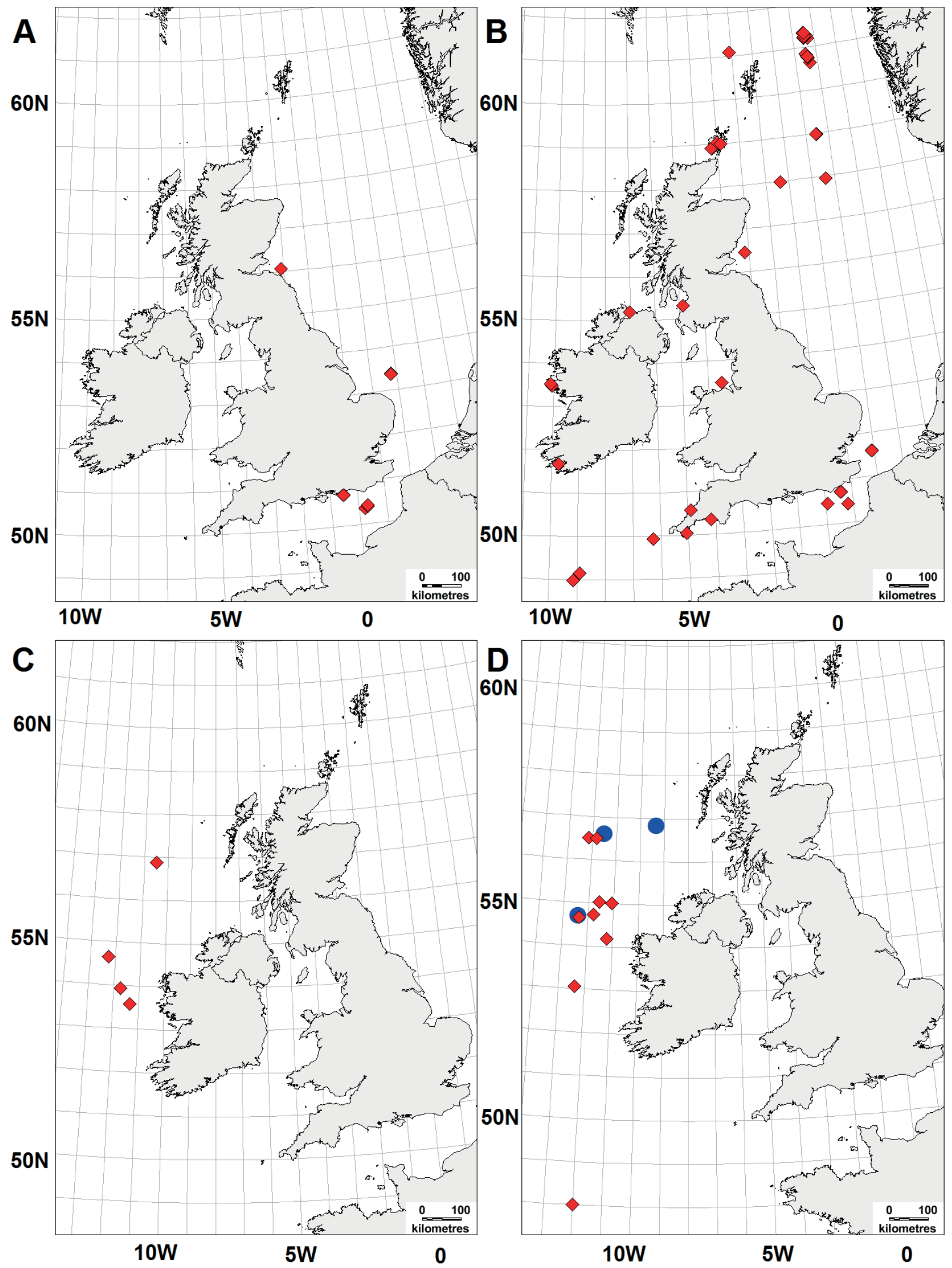

Figure 2. Distribution of Leptostraca in the British Isles: (A) Nebalia borealis Dahl, 1985; (B) Sarsinebalia urgorrii Moreira, Gestoso and Troncoso, 2003; (C) Sarsinebalia typhlops (G.O. Sars, 1870); (D) Nebaliella caboti Clark, 1932 (denoted by blue circles); Nebaliopsis typica G.O. Sars, 1887 (red diamonds). 
a different species as the dimensions of the maxilla 2 in Ledoyer's specimens differ from that typical of the species [in Dahl's (1985) description the proximal article of the endopod is longer than the distal article, whereas in Ledoyer's specimen they are subequal in length]. Subsequent to Dahl's (1985) revision many of the records that were originally ascribed to Nebalia bipes within the British Isles were ascribed to N. herbstii but these records should be treated with caution and deposited specimens re-examined in the light of the new records submitted for the British Isles. All 16 specimens of $N$. herbstii from Loch Fyne had epibionts similar to those discussed above for N. kocatasi.

\section{Nebalia borealis Dahl, 1985}

Material examined. North Sea. 1 specimen, Clipper Field, 53 $23.071^{\prime} \mathrm{N} 001^{\circ} 47.078^{\prime} \mathrm{E}, 25.9$ m, muddy sand, 7.ii.2009 (OUMNH.ZC.2016-01-006, 1 specimen). 1 specimen, Clipper Field, 5322.121'N 00146.887'E, $27.1 \mathrm{~m}$, muddy sand, 5.ii.2009. Scotland. 1 specimen, St. Abbs, 56 03.440’N 002 07.270’ W, 56 m, 30.vi.1987 [specimen previously cited by O'Reilly et al. (2001) as N. herbstii]. England. $1 \delta^{\lambda}$, eastern English Channel, $50^{\circ} 43.0174$ 'N $0^{\circ} 31.0028^{\prime} \mathrm{W}, 14.7 \mathrm{~m}$, muddy sandy gravel and pebbles, 15.vii.2015. 1 specimen, eastern English Channel, 50²1.968’ N 000¹2.759'E, 45 $\mathrm{m}$, sandy gravel, 31.vii.2014. 11 specimens, eastern English Channel, 50²3.835’N 000¹9.243’E, 48.1 m, sandy gravel, 31.vii.2014. 1 specimen, eastern English Channel, 50²5.786’ N 000 $18.418^{\prime} \mathrm{E}, 54.1 \mathrm{~m}$, sandy gravel, 7.viii.2014.

British and Irish Distribution. Shetland Islands (Dahl, 1985); North Sea, St. Abbs, Scotland, English Channel (present study) (Fig. 2A).

Distribution beyond the study area. Norway, Sweden (Dahl, 1985).

Ecology. Clay, muddy sands to sandy gravels and rocky bottoms at depths of $14 \mathrm{~m}$ to $350 \mathrm{~m}$.

Remarks. The specimens examined here agree well with Dahl's description of the species. One of the specimens cited under the name N. herbstii by O'Reilly et al. (2001), with the caveat that only specimens for
1989 had been confirmed, was re-examined here and found to be $N$. borealis. This species has a northern distribution and the present records extend the southern range of the species southwards in the British Isles to the central English Channel.

\section{Genus Sarsinebalia Dahl, 1985}

Remarks. Dahl (1985) created the genus Sarsinebalia to accommodate Nebalia typhlops, and based it on four characters: 1 ) a complicated rostrum with subterminal spine; 2) the features of the eye; 3 ) lack of a combrow on the exopod of the first pleopod; and 4) a short exopod of the 2 nd maxilla. Dahl (1985) goes on to state that these features are also present in an undescribed species from the Red Sea [according to Moreira et al. (2003) this is corrected to north-west Africa in an unpublished manuscript by Dahl] and two further undescribed species from Australia. Moreira et al. (2003) postulate that the north-west African species could be could be identical to their Sarsinebalia urgorrii Moreira, Gestoso and Troncoso, 2003 whilst the identity of the Australian species is unknown as descriptions of these taxa had not appeared at the time of Dahl's death. To date, five species have been ascribed to Sarsinebalia: S. typhlops, S. urgorrii, Sarsinebalia cristoboi Moreira, Gestoso and Troncoso, 2003, Sarsinebalia biscayensis Ledoyer, 1998, and Sarsinebalia kunyensis Ledoyer, 2000. According to Mauchline and Gage (1983) and Dahl (1985), specimens recorded from New Jersey, U.S.A. by Hessler and Sanders (1965) as Nebalia typhlops occidentalis Hessler and Sanders, 1965 differ in several significant characters and could represent a further species.

Walker-Smith and Poore (2001) considered Sarsinebalia to be a synonym of Nebalia but only included the type species $S$. typhlops in their analysis. However, Moreira et al. (2003) retained Sarsinebalia as valid as some (but not all) of the characters proposed by Dahl (1985) hold between S. typhlops, S. urgorrii and S. cristoboi. However, their study likewise overlooked $S$. biscayensis and S. kunyensis. A recent key to worldwide Nebalia species (Song and Min, 2016) also did not adopt the synonymy of Sarsinebalia suggested by Walker-Smith and Poore (2001).

Since Dahl's (1985) landmark study there have been significant advances in the taxonomy and systematics 
of the Leptostraca with around $67 \%$ of the currently accepted species having been described since this date with further new species continuing to be described (e.g. Koçak and Moreira, 2015; Song and Min, 2016). Combined with the phylogenetic studies of Olesen (1999) and Walker-Smith and Poore (2001), there is now a greater, if still not complete, understanding of variation in the traditionally used diagnostic characters across the Leptostraca. Many of Dahl's diagnostic characters for Sarsinebalia no longer stand up to scrutiny and now appear to be more indicative of species- rather than genus-level differences. These are discussed in turn here.

1) Complicated rostrum with subterminal spine. All species of Nebalia have a rostral keel (WalkerSmith and Poore, 2001) so in this respect the rostrum of Sarsinebalia species is no more complex. The subterminal spine is present in Sarsinebalia and the undescribed Nebalia sp. B of Walker-Smith and Poore (2001) as well as the less closely related genera of the Paranebaliidae. Additionally, S. biscayensis has a reduced spine (see Ledoyer, 1998), and some mature males of S. typhlops are also noted by Dahl (1985) as having a reduced spine.

2) Features of the eye. Of the five nominal species, only S. typhlops (and possibly the undescribed species of Dahl, 1985) has the 'squarish' eye shape described by Dahl (1985). The eyes of S. urgorrii and S. cristoboi are of a similar but not identical shape, whilst S. biscayensis has long slender eyes (see Ledoyer, 1998) and S. kunyensis appears to have rounded eyes (see Ledoyer, 2000). Eye shape is exceptionally variable in other Nebalia (even as far as being bi-lobed - see Walker-Smith and Poore, 2001) so a 'squarish' eye seems not to be too unusual and certainly within the range of variation covered by other Nebalia. In addition, Hessler (1984) illustrated significant developmental changes in the shape and armature of the eye of Dahlella caldariensis Hessler, 1984. Pigment is absent in S. biscayensis, $S$. kunyensis and $S$. typhlops but present in the $S$. urgorrii and S. cristoboi (but also seems to fade after long-term storage in alcohol, in S. urgorrii at least). As a general rule within the Crustacea, there is a tendency towards unpigmented eyes in deeper water species which may explain its absence in S. biscayensis, S. kunyensis and $S$. typhlops which are found deeper than S. urgorrii and S. cristoboi. Ommatidia are absent in S. typhlops and
S. biscayensis but present in the other three species (also absent in unrelated Speonebalia Bowman, Yager and Iliffe, 1985, Nebaliella Thiele, 1904, and Dahlella Hessler, 1984).

3) Lack of a comb-row on the exopod of the first pleopod. A comb-row is absent in S. typhlops, S. urgorrii and $S$. cristoboi but present in both $S$. biscayensis and S. kunyensis. The length of the comb-row appears to be diagnostic (at least partially so) at a species level in Nebalia (see Walker-Smith and Poore, 2001) and the complete absence of a comb-row could just represent the extreme of this variation.

4) A short exopod of the 2nd maxilla. Only $S$. typhlops and S. biscayensis have an unusually short exopod on maxilla 2 , whereas the other species have an exopod longer than the first segment of the endopod. In S. kunyensis and S. biscayensis the division between the two endopod segments is indistinct but the length of the exopod relative to the overall endopod can be used.

Based on this, the only character that is consistent between all 5 species of Sarsinebalia is the presence of a subterminal rostral spine. As already mentioned this spine occurs elsewhere in the Paranebaliidae and in Walker-Smith and Poore's (2001) Nebalia sp. B and so is not unique to Sarsinebalia. A formal reappraisal of Sarsinebalia is outside of the scope of the current study and should await examination of material of the currently included species as it is conceivable that other, as yet un-investigated, characters may unite all or some of the species currently assigned to the genus. Molecular methods may also help resolve the status of the genus. Until such time we continue to use Sarsinebalia here in accordance with Moreira et al. (2003).

\section{Sarsinebalia urgorrii Moreira, Gestoso and Troncoso, 2003}

Material examined. Ireland. 19 , Mannin Bay, Co. Galway, 53²8.3919'N 105.118’W, 9.9 m, sand, 16.x.2010.2 $\bigcirc^{\lambda}, 37 q$ and 8 juveniles, Kingstown Bay, Co. Galway, 5330.9829’ N 108.22’W, 9.3 m, gravelly sand, 16.x.2010.1 1 , Ahabeg, Bantry Bay, Co. Cork, under a cage at stocked salmon farm located at $51^{\circ} 39.7302^{\prime} \mathrm{N}$ 009 45.1727'W, 20-24.5 m, mud interspersed with shelly sand, 29.viii.2013. 16 9 , Ahabeg, Bantry Bay, Co. Cork, near edge of stocked salmon farm located 
at $51^{\circ} 39.7302^{\prime} \mathrm{N} 009^{\circ} 45.1727^{\prime} \mathrm{W}, 20-24.5 \mathrm{~m}$, shelly gravel, 29.viii.2013 (NMINH:2016.1.6, 2 ㅇ). 2 specimens, Lough Foyle, Co. Donegal, 55 $11.510^{\prime} \mathrm{N}$ $007^{\circ} 00.765^{\prime} \mathrm{W}, 9.5 \mathrm{~m}$, sand with shell, 29.iii.2012. 3

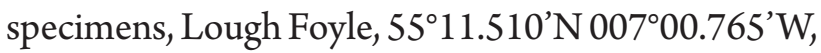
$15.6 \mathrm{~m}$, sand with shell, 26.vi.2013. North Sea. 9 specimens, Osprey Field, 61¹9.530’N 001³2.601'E, $159.9 \mathrm{~m}$, muddy sand, 6.xii.2008. 1 specimen, Osprey Field, 61²19.249’ N 001³4.643’E, 159.5 m, muddy sand, 7.xii.2008. 2 specimens, Osprey Field, $61^{\circ} 20.318^{\prime} \mathrm{N} 001^{\circ} 31.633^{\prime} \mathrm{E}, 160.1 \mathrm{~m}$, muddy sand, 7.xii.2008. 2 specimens, Osprey Field, $61^{\circ} 19.257^{\prime} \mathrm{N}$ $001^{\circ} 34.653^{\prime} \mathrm{E}, 158.6 \mathrm{~m}$, muddy sand, 7.xii.2008. 1 specimen, Osprey Field, 61 ${ }^{\circ} 19.102^{\prime} \mathrm{N} 001^{\circ} 32.295^{\prime} \mathrm{E}$, $159.1 \mathrm{~m}$, muddy sand, 6.xii.2008. 1 specimen, Osprey

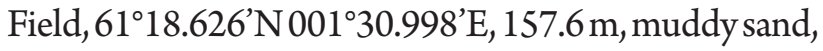
4.xii.2008. 2 specimens, Dunlin Field, $61^{\circ} 12.819^{\prime} \mathrm{N}$ 001 $30.926^{\prime}$ E, 149.09 m, muddy sand, 9.xi.2009. 1 specimen, Dunlin Field, 61 $12.151^{\prime} \mathrm{N} 001^{\circ} 41.738^{\prime} \mathrm{E}$, $145.8 \mathrm{~m}$, muddy sand, 11.xi.2009. 1 specimen, Dunlin Field, $61^{\circ} 15.547^{\prime} \mathrm{N} 001^{\circ} 39.227^{\prime} \mathrm{E}, 151.5 \mathrm{~m}$, muddy sand, 11.xi.2009 (OUMNH.ZC.2016-01-012, 1 specimen). 1 specimen, Dunlin Field, 61 ${ }^{\circ} 16.961^{\prime} \mathrm{N}$ 001 ${ }^{\circ} 33.856^{\prime} \mathrm{E}, 153.2 \mathrm{~m}$, muddy sand, 11.xi.2009. 1 specimen, Dunlin Field, 61 12.911'N 001'30.772’E, 148.45 m, muddy sand, 9.xi.2009. 1 specimen, Dunlin Field, $61^{\circ} 12.908^{\prime} \mathrm{N} 001^{\circ} 30.776$ 'E, 148.39 m, slightly gravelly muddy sand, 9.xi.2009. 1 specimen, Dunlin Field, $61^{\circ} 12.921^{\prime} \mathrm{N} 001^{\circ} 30.438^{\prime} \mathrm{E}, 148.9$ m, muddy sand, 9.xi.2009. 1 specimen, Dunlin Field, 61 ${ }^{\circ} 13.140^{\prime} \mathrm{N}$ $001^{\circ} 30.883^{\prime} \mathrm{E}, 148.4 \mathrm{~m}$, muddy sand, 8.xi.2009. 1 specimen, Dunlin Field, $61^{\circ} 15.052^{\prime} \mathrm{N} 001^{\circ} 33.887^{\prime} \mathrm{E}$, $149.9 \mathrm{~m}$, slightly gravelly muddy sand, 8.xi.2009. 2 specimens, Dunlin Field, 61 $14.780^{\prime} N$ 001⒊292’E, $149.1 \mathrm{~m}$, slightly gravelly muddy sand, 8.xi.2009. 1 specimen, Dunlin Field, 6046.631'N 001³3.047’E, $141.4 \mathrm{~m}$, muddy sand, 20.v.2010. 1 specimen, Glenlivet Field, $61^{\circ} 04.600^{\prime} \mathrm{N} 002^{\circ} 05.420^{\prime} \mathrm{W}, 435 \mathrm{~m} .1$ specimen, Staffa Field, $60^{\circ} 44.490^{\prime} \mathrm{N} 001^{\circ} 35.349^{\prime} \mathrm{E}, 135.5 \mathrm{~m}$, muddy sand, 17.ix.2009. 2 specimens, Staffa Field, $60^{\circ} 49.431^{\prime} \mathrm{N} 001^{\circ} 30.370^{\prime} \mathrm{E}, 134.9 \mathrm{~m}$, muddy sand, 20.v.2010. 3 specimens, Staffa Field, $60^{\circ} 47.964^{\prime} \mathrm{N}$ $001^{\circ} 31.698^{\prime} \mathrm{E}, 138.7 \mathrm{~m}$, muddy sand, 20.v.2010. 1 specimen, Staffa Field, 6044.405’N 001³4.707’E, $138.6 \mathrm{~m}$, muddy sand, 16.v.2010. 2 specimens, Staffa Field, $60^{\circ} 45.327^{\prime} \mathrm{N} 001^{\circ} 34.281^{\prime} \mathrm{E}, 139.3 \mathrm{~m}$, muddy sand, 17.v.2010. 1 specimen, Staffa Field, $60^{\circ} 47.964^{\prime} \mathrm{N}$ $001^{\circ} 31.697^{\prime} \mathrm{E}, 138.7 \mathrm{~m}$, slightly gravelly muddy sand, 20.v.2010 (OUMNH.ZC.2016-01-011, 1 specimen). 1 specimen, Staffa Field, 6046.631'N 001³3.047'E, 141.4 m, muddy sand, 20.v.2010. 1 specimen, Staffa Field, $60^{\circ} 50.390^{\prime} \mathrm{N} 001^{\circ} 29.613^{\prime} \mathrm{E}, 134.4 \mathrm{~m}$, slightly gravelly muddy sand, 20.v.2010. 7 specimens, Staffa Field, 6050.390’N 001²9.612’E, 134.35 m, slightly gravelly muddy sand, 20.v.2010. 1 specimen, Staffa Field, $60^{\circ} 49.431^{\prime} \mathrm{N} 001^{\circ} 30.370^{\prime} \mathrm{E}, 134.9 \mathrm{~m}$, slightly gravelly muddy sand, 20.v.2010. 1 specimen, Staffa Field, $60^{\circ} 47.964^{\prime} \mathrm{N} 001^{\circ} 31.698^{\prime} \mathrm{E}, 138.7 \mathrm{~m}$, slightly gravelly muddy sand, 20.v.2010. 7 specimens, Dunbar Field, 603 $3700^{\prime} \mathrm{N} 001^{\circ} 39.200^{\prime} \mathrm{E}, 145 \mathrm{~m} .2$ specimens, Braemar Field, 5858.991’N 001²7.840’E, 118 m, sandy mud, 21.xi.2012. 1 specimen, Braemar Field, $58^{\circ} 58.360^{\prime} \mathrm{N} 001^{\circ} 26.961^{\prime} \mathrm{E}, 124 \mathrm{~m}, \mathrm{MDAC}$ mud and shell, 21.xi.2012. 1 specimen, Goldeneye Field, $57^{\circ} 58.921^{\prime} \mathrm{N} 000^{\circ} 23.452^{\prime} \mathrm{W}, 122 \mathrm{~m}$, muddy sand, 15.i.2010. 1 specimen, Nelson Field, 5756.500’N $001^{\circ} 36.683^{\prime} \mathrm{E}, 95 \mathrm{~m}$, muddy sand, 12.xii.2013. Scotland. 1 specimen, Bring Head, Hoy, Orkney, $58^{\circ} 53.702^{\prime} \mathrm{N} 003^{\circ} 15.115^{\prime} \mathrm{W}, 23 \mathrm{~m}$, sand, 17.i.2012 (OUMNH.ZC.2016-01-010). 1 specimen, Bring Head, Hoy, Orkney, 5854.050’N 003¹6.191'W, 20 $\mathrm{m}$, sand, 17.i.2012. 1 specimen, Bring Head, Hoy, Orkney, 58 $53.702^{\prime} \mathrm{N} 003^{\circ} 15.115^{\prime} \mathrm{W}, 23 \mathrm{~m}$, sand, 17.i.2012. 1 specimen, Bring Head, Hoy, Orkney, $58^{\circ} 53.765^{\prime} \mathrm{N} 003^{\circ} 15.115^{\prime} \mathrm{W}, 21.8 \mathrm{~m}$, sand, 19.ix.2013. 1 specimen, Bring Head, Hoy, Orkney, 58 $54.050^{\prime} \mathrm{N}$ $003^{\circ} 16.191^{\prime} \mathrm{W}, 19 \mathrm{~m}$, sand, 19.ix.2013. 1 specimen, Kirkwall Bay, Orkney, 5900.864’N 00257.872’W, $11 \mathrm{~m}, 25 . v .2014 .5$ specimens, Kirkwall Bay, Orkney, 59 02.014'N 002 59.722'W, 13 m, 25.v.2014. 1 specimen, Kirkwall Bay, Orkney, 58 59.729’ N $002^{\circ} 49.951^{\prime} \mathrm{W}, 19 \mathrm{~m}, 25 . v .2014 .3$ specimens, Bell Rock, 56²7.000’N 002¹0.000’W, 53 m, 24.iv.1989 [specimen previously cited by O'Reilly et al. (2001) as S. typhlops]. 1 specimen, Girvan Mains, 55 $15.780^{\prime} \mathrm{N}$ 00451.790’W, 30.viii.2000. England. 1 specimen, Plymouth Sound, 50²0.333'N 004 $10.567^{\prime}$ W, 6.3 $\mathrm{m}$, coarse sand, 30.iii.2011. 1 specimen, Padstow, Cornwall, 50³4.263’ N 00457.480’W, $11.9 \mathrm{~m}$, sand with shell, 12.iii.2013. 2 specimens, Lizard Peninsula, Cornwall, 5002.550’ N 00503.998'W, 10.5 m, muddy coarse sand, 13.vii.2014. 1 specimen, north-east Isles of Scilly, $49^{\circ} 56.194^{\prime} \mathrm{N} 006^{\circ} 16.593^{\prime} \mathrm{W}, 18.8 \mathrm{~m}$, fine sand, 26.v.2013. 1 specimen, South West Deeps rMCZ, 
$48^{\circ} 58.885^{\prime} \mathrm{N} 009^{\circ} 08.731^{\prime} \mathrm{W}, 161 \mathrm{~m}$, sand, 17.v.2013. 1 specimen, South West Deeps rMCZ, 49 $08.603^{\prime} \mathrm{N}$ 008 54.977'W, 154 m, muddy sand, 13.v.2013. 1 specimen, eastern English Channel, 5043.7117’ $\mathrm{N}$ $0^{\circ} 34.5528^{\prime} \mathrm{E}, 24.5 \mathrm{~m}$, sandy gravel, 7.vi.2015. 1 specimen, eastern English Channel, 50²6.046’ $\mathrm{N}$ $000^{\circ} 48.017^{\prime} \mathrm{E}$, $44.1 \mathrm{~m}$, gravelly sand, 1.viii.2014. 1 specimen, eastern English Channel, 50²9.212’ N $000^{\circ} 04.533$ 'E, $56.8 \mathrm{~m}$, gravelly sand, 4.viii.2014. 1 specimen, South Falls Disposal Ground, Outer Thames, $51^{\circ} 34.3416^{\prime} \mathrm{N} 1^{\circ} 58.3548^{\prime} \mathrm{E}, 49 \mathrm{~m}$, muddy sand with clay, 2.xi.2014. 1 specimen, Liverpool Bay, 5328.641'N $003^{\circ} 29.659^{\prime} \mathrm{W}$, sandy gravel, 29.x.2014.

British and Irish Distribution. North, west and southwest Ireland (Co. Donegal, Co. Galway and Co. Cork), North Sea, Orkney Islands, Firth of Clyde, English Channel, Cornwall, Isles of Scilly, South West Deeps (Fig. 2B).

Distribution beyond the study area. Galicia, NW Iberian Peninsula (Moreira et al., 2003; 2009a). Based on the previously known distribution and the present records it seems likely that this species is also present along the west coast of France and continental southern North Sea coasts but this requires confirmation.

Ecology. Coarse sandy sediments, from very coarse sand to medium sand, at depths of $12.7-20 \mathrm{~m}, 1.4-3.7 \%$ TOM (Moreira et al., 2009a). Coarse shelly gravel to mud at depths 9.3-435 m, 9.03-14.73\% TOM (present study).

Remarks. Based on the current records, S. urgorrii is the dominant species of Sarsinebalia in shallow British and Irish waters. The pigmentation of the eyes was variable in the present material ranging from dark to orange and occasionally being almost completely absent; when this was the case externally visible ommatidia were still evident. The examined material generally agreed with the description of Moreira et al. (2003) but in one female from the English Channel six spines were noted on the distolateral border of the sixth pleopod rather than four as stated in the diagnosis provided by Moreira et al. (2003). All other characters agreed well with $S$. urgorrii.

\section{Sarsinebalia typhlops (G.O. Sars, 1870)}

\section{Material examined. None.}

British and Irish Distribution. Rockall Trough, 1990$2900 \mathrm{~m}$ (Mauchline and Gage, 1983), west of Ireland (Tattersall, 1905) (Fig. 2C).

Distribution beyond the study area. Widespread; Red Sea, Lofoten Is. (Norway), Messina, Bay of Naples (Italy), North America from Davis Strait to New Jersey, Australia (Walker-Smith and Poore, 2001). Records should be examined as it is possible that some may refer to undescribed species.

Remarks. Previous British and Irish records of $S$. typhlops require confirmation in light of the present study where only $S$. urgorrii was recorded amongst abundant material from shallow waters (much of which was originally identified as $S$. typhlops following Mauchline, 1984). It is likely that S. typhlops is restricted to deeper waters in the area (Mauchline and Gage, 1983).

\section{Genus Nebaliella Thiele, 1904}

\section{Nebaliella caboti Clark, 1932}

Material examined. None.

British and Irish Distribution. Rockall Trough, 1390-2900 m (Mauchline and Gage, 1983) (Fig. 2D).

Distribution beyond the study area. Cabot Strait, eastern Canada at $378 \mathrm{~m}$ (type locality - Clark, 1932), off New Jersey, U.S.A., 2085 m (Hessler and Sanders, 1965).

Remarks. Although Mauchline and Gage (1983) referred their specimens to $N$. caboti they did so with some reservation given the uncertainty surrounding the systematics of Nebaliella at that time and stated that comparative studies should be made of all Nebaliella species to help resolve these issues. Such a study was conducted by Walker-Smith (1998) who reviewed Mauchline and Gage's (1983) record accepting their identification in addition to providing other characters 
useful for separating N. caboti from its congeners.

\section{Family Nebaliopsididae Hessler, 1984}

\section{Genus Nebaliopsis G.O. Sars, 1887}

\section{Nebaliopsis typica G.O. Sars, 1887}

\section{Material examined. None.}

British and Irish Distribution. South-west British Isles (Linder, 1943), Rockall Trough (Mauchline and Gage, 1983) (Fig. 2D).

Distribution beyond the study area. Described from the South Pacific midway between New Zealand and Chile (Sars, 1887). Considered to be near cosmopolitan between the latitudes $50^{\circ} \mathrm{N}$ and $50^{\circ} \mathrm{S}$ (Mauchline, 1984). West and south-east coast of South America, near Falkland Is., off coast of Ghana, Ivory Coast, south-west Indian Ocean, South Pacific, Scotia Sea (Walker-Smith and Poore, 2001).

\section{DISCUSSION}

Prior to the present study, five species of Leptostraca were recorded from the British Isles. These are Nebalia herbstii, Nebalia borealis, Sarsinebalia typhlops, Nebaliella caboti and Nebaliopsis typica. In light of the present research, the number of leptostracan species recorded in the British Isles is nine, as outlined above. These records provide further evidence to support Dahl's (1985) removal of $N$. bipes from the British species list and demonstrate that, despite the previous works, the leptostracan fauna of the British Isles was poorly known.

Our records indicate that the dominant species in shallow, offshore waters of the British Isles are $N$. reboredae and S. urgorrii, neither of which has previously been formally reported for the region. Many of the current records are from routine monitoring projects, in coastal and offshore waters and collected using grab samplers, dredges and diver cores. The distributions presented here are therefore influenced to a degree by the sampling methods, sampling intensity, target habitats and the drivers of these surveys. For example, we have few records from intertidal areas (the exception being $N$. kocatasi as outlined above) and comparatively few from very shallow near-shore locations. It is possible that targeted sampling for leptostracans using other methods such as light traps may yield further records of species new to the area and provide a better understanding of the distribution of each species in the region.

Historically, the distribution and identity of leptostracans in European waters has been problematic, although several recent studies beginning with Dahl (1985) have contributed greatly to our understanding of the group in Europe. In order to help clarify species ranges and consistently identify specimens a key to the currently described Leptostraca of Europe is provided below. Given the highly conservative morphology of leptostracans, it is likely that molecular studies will demonstrate that some of the currently accepted species in fact represent species complexes, particularly for some of the more wide-ranging species. Furthermore, as new species continue to be described and further works are likely to provide insights into variability of character states, this key should be regarded as provisional rather than definitive at this stage and identifications should be carefully compared with original descriptions where possible. Several studies, most notably that of Olesen and Walossek (2000), have discussed ontogenetic changes in some taxonomically important characters such as antennae, maxillae and pleopods. Males for some species are unknown or poorly described. The key is therefore based on adult females and using this key for males or immature specimens could result in incorrect identifications. Staining specimens in Methyl Green improves the visibility of certain characters and may aid in the accurate identification of specimens. In particular it makes it possible to discern the relative lengths of the articles of the second maxilla without dissection.

\section{Key to the adult females of leptostracan species from European waters}

1. Caudal furcae leaf-like, broadest midway; rostral plate small 
2. Rostrum with ventral keel longer than rostral flange; thoracopods $2-5$ without epipods; eye modified into leaf-like appendage; molar with accessory spine

Nebaliella caboti Clark, 1932

2'. Rostrum with keel shorter than rostral flange (Fig. 4A, B); thoracopods 2-5 with epipod that is longer than exopod; eye of different form; molar without accessory spine

3. Rostrum with small subterminal spine (may be difficult to discern) (Fig. 4B) ........................ [Sarsinebalia] 4

3. Rostrum lacking subterminal spine (Fig. 4A) . $\left[\right.$ Nebalia $\left.^{*}\right] 7$

4. Dorsal denticles of pleonites 6-7 with distally acute denticles; exopod of pleopod 1 with a spine row of about 12 spines with simple apices; antennule peduncle article 4 without spine; subterminal spine of rostrum small Sarsinebalia biscayensis Ledoyer, 1998

4' Dorsal denticles of pleonites 6-7 with distally rounded denticles; exopod of pleopod 1 without spine row; antennule peduncle article 4 with spine; subterminal spine of rostrum well developed (may be reduced in adult males)

5. Eye lacking pigment and externally discernable visual elements; exopod of maxilla 2 shorter than first article of endopod. Sarsinebalia typhlops (G.O. Sars, 1870)

5. Eye provided with pigment and ommatidia (although colour may have faded following preservation in alcohol); exopod of maxilla 2 longer than first article of endopod....

6. Supraorbital scale surpassing distal end of eye; antennal flagellum with thin long setae; pleonite 4 posterior border with acute denticles. S. cristoboi Moreira et al., 2003

6. Supraorbital scale not surpassing distal end of eye; antennal flagellum with short spine-like setae; pleonite 4 posterior lateral border with distally rounded to pointed denticles

7. Pleonites 6-7 provided with distally acute denticles (Fig. 3A, D) S. urgorrii Moreira et al., 2003

7'. Pleonites 6-7 provided with denticles of a different shape (Fig. 3A, C) . 8

8. Antennular flagellum with more than 10 articles; antennular scale more than twice as long as wide ........... 9

8. Antennular flagellum with up to 7 articles; antennal scale twice as long as wide

Nebalia troncosoi Moreira et al., 2003

9. Terminal dorsal spine of peduncle of pleopod 1 reaching nearly to end of spine row; exopod of 2 nd maxilla extends past proximal article of endopod Nebalia borealis Dahl, 1985

9. Terminal dorsal spine of peduncle of pleopod 1 reaching at most to centre of spine row; exopod of 2 nd maxilla barely extends past proximal article of endopod. Nebalia strausi Risso, 1826

10. Eyes pigmented 11

10'. Eyes lacking pigment Nebalia abyssicola Ledoyer, 1997

11. Proximal article of the endopod of 2 nd maxilla longer than distal article [Fig. 4D ( $a>b)$ ] 12

11'. Proximal article of the endopod of 2 nd maxilla of equal length to the distal article [Fig. 4E ( $\left.\left.\mathrm{a}^{\prime}=\mathrm{b}^{\prime}\right)\right]$; lateral external armature of the antenna, article 3, consists of 3 thin setae and three spine-like setae (Fig. 5A, shaded); proximal spine-like seta (Fig. 5A, arrowed, shaded) shorter than other two

Nebalia kocatasi Moreira et al., 2007

12. Exopod of 2nd maxilla extends past the proximal article of the endopod (Fig. 4D) ..... 13

12. Exopod of 2nd maxilla does not extend past the proximal article of the endopod ... Nebalia clausi Dahl, 1985

13. Antennular flagellum with more than 10 articles; antennule peduncle article 4 with three or more distal thick spines

13. Antennular flagellum with less than 10 articles; antennule peduncle article 4 with one distal thick spine (Fig. 3B)

14. Anal scale with point lying over mid-line of the scale (Fig. 5B); (endopod of thoracopods $2-7$ in praeovigerous females extend well past exopod); distal article of mandible palp with parallel margins (Fig. 5E) ... Nebalia herbstii Leach, 1814

14. Anal scale with point lying closer to medial margin (Fig. 5C); (endopod of thoracopods $2-7$ in prae-ovigerous females reaching only level with or just past exopod); distal article of mandible palp with margins diverging (Fig. 5D) Nebalia bipes (Fabricius, 1780) 
15. Pleopod 4 protopod without serrations along posterior border

Nebalia reboredae Moreira and Urgorri, 2009 in Moreira et al., 2009a

15. Pleopod 4 protopod with 4 serrations along posterior border (as in Fig. 4C); lateral external armature of the antenna, article 3, consists of 3 thin setae and 3 spine-like setae (spine-like setae of equal length)

Nebalia mediterranea Koçak and Moreira, 2015

* A further species, Nebalia biarticulata Ledoyer, 1997, has been described from the Mediterranean French coast. In the original description of the species, Ledoyer (1997) stated that all the specimens are presumed to be male, due to the length of the antennae in relation to the body. No additional specimens of this species have been reported upon since its discovery and the female is unknown. It is possible that it represents the male of one of the other species known from the Mediterranean region and that the two have not yet been linked but since no confirmed females are known it is omitted from this key. The species is characterised by possessing a biarticulate pleopod 6. According to the most recent diagnosis of Nebalia (Walker-Smith and Poore, 2001) this character should exclude N. biarticulata from the genus Nebalia in which the sixth pleopod is uniarticulate. A biarticulate sixth pleopod is otherwise found in Nebaliopsis (Nebaliopsidae), Speonebalia and Nebaliella (both Nebaliidae). A re-examination of this species may prove worthwhile.
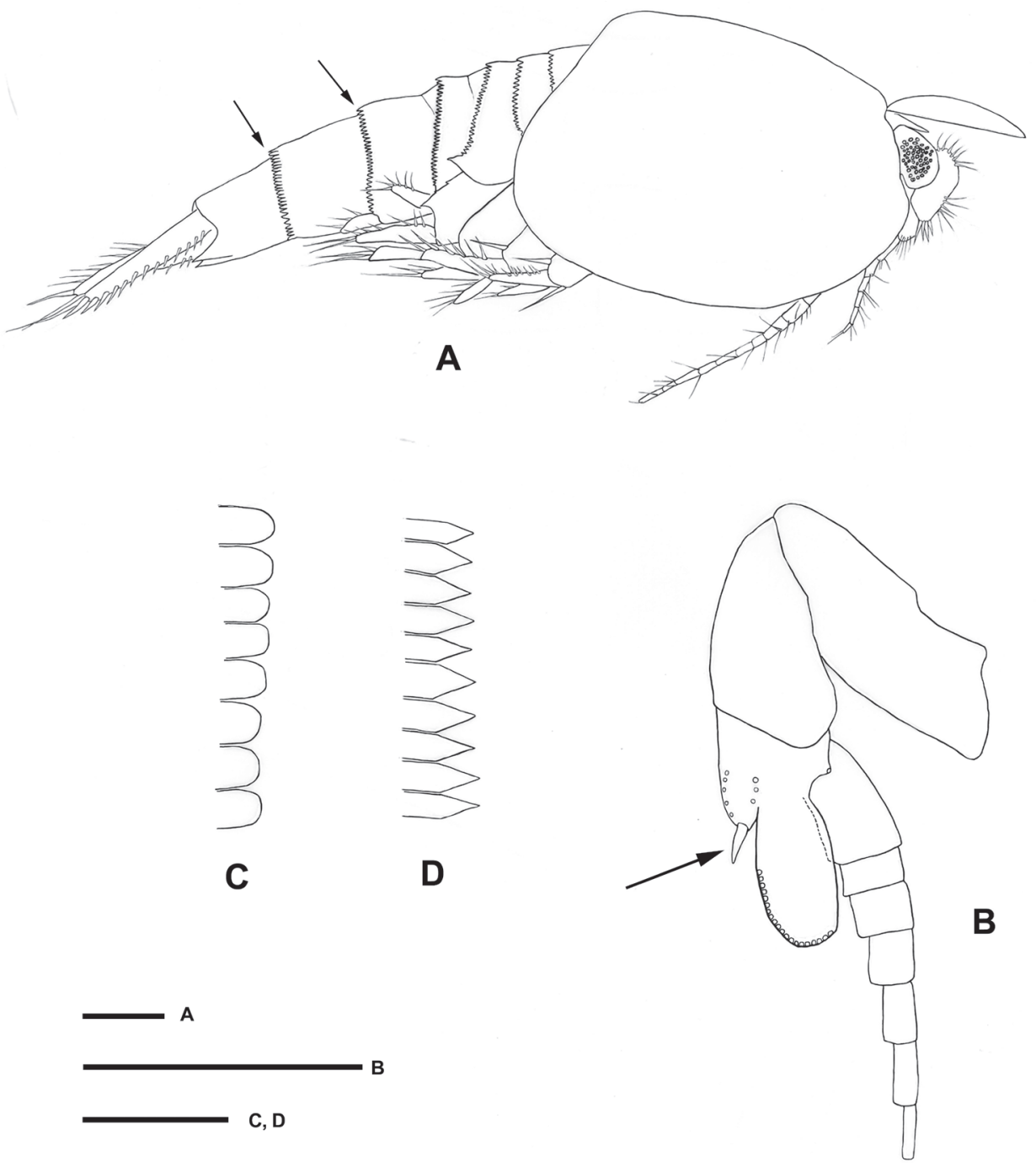

Figure 3. (A) Nebalia kocatasi female habitus (position of denticles on posterior margin of pleonite 6 and 7 arrowed); (B) N. reboredae antennule (antennule peduncle article 4 with one thick spine arrowed, setae omitted); (C) N. kocatasi denticles at posterior margin of pleonite 7; (D) N. strausi denticles at posterior margin of pleonite 7 . Scale bars: A, $0.5 \mathrm{~mm}$; B-D $0.1 \mathrm{~mm}$. 

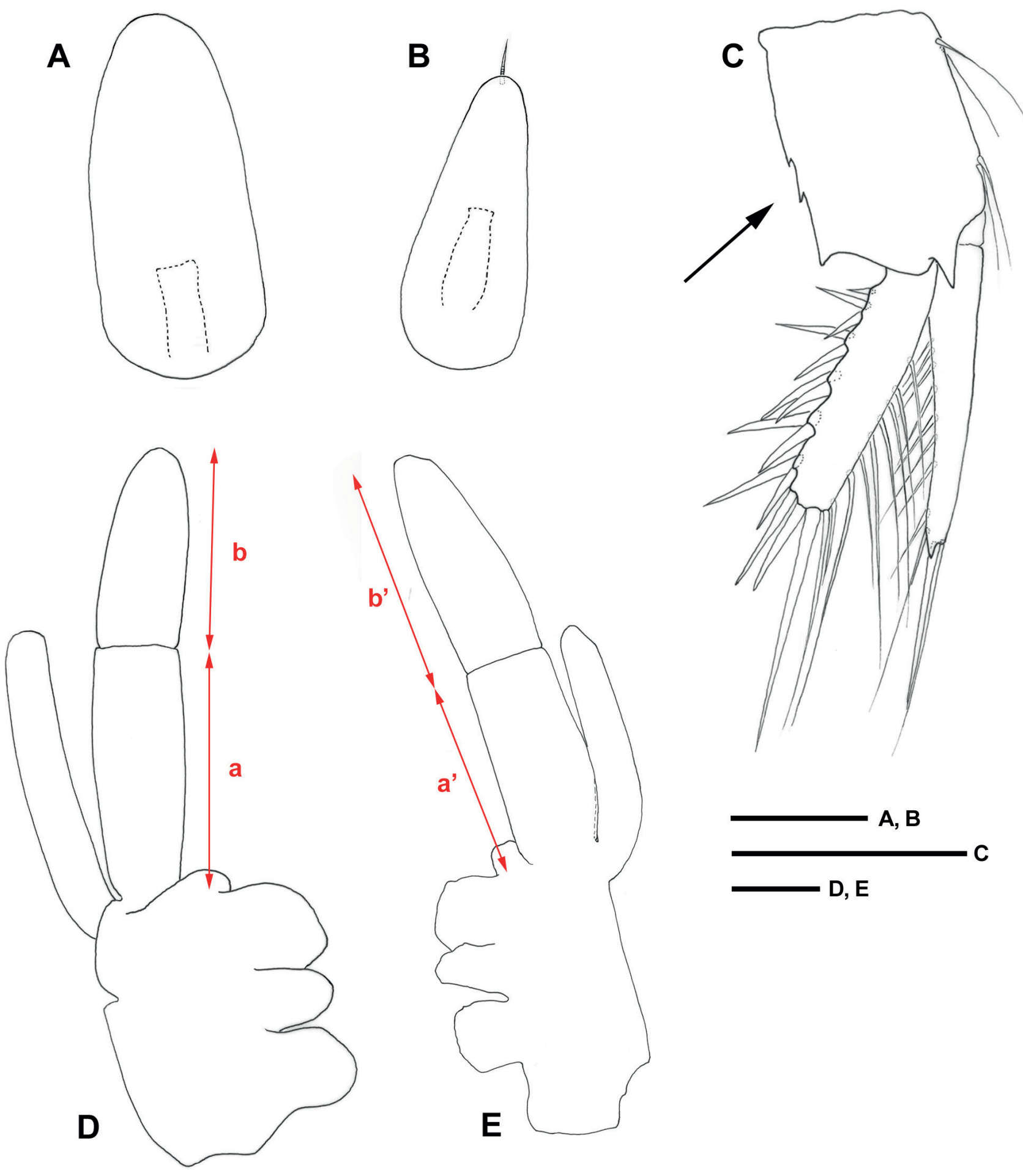

Figure 4. (A) Nebalia kocatasi rostrum, dorsal view (ventral rostral keel outlined); (B) Sarsinebalia urgorrii rostrum, dorsal view (ventral rostral keel outlined); (C) N. kocatasi pleopod 4 (serrated margin arrowed); (D) N. reboredae maxilla 2 (length of a $>b$, setae omitted); (E) N. kocatasi maxilla 2 (length of a' = b', setae omitted). Scale bars: A, B, D, E, 0.1 mm; C 0.5 mm. 


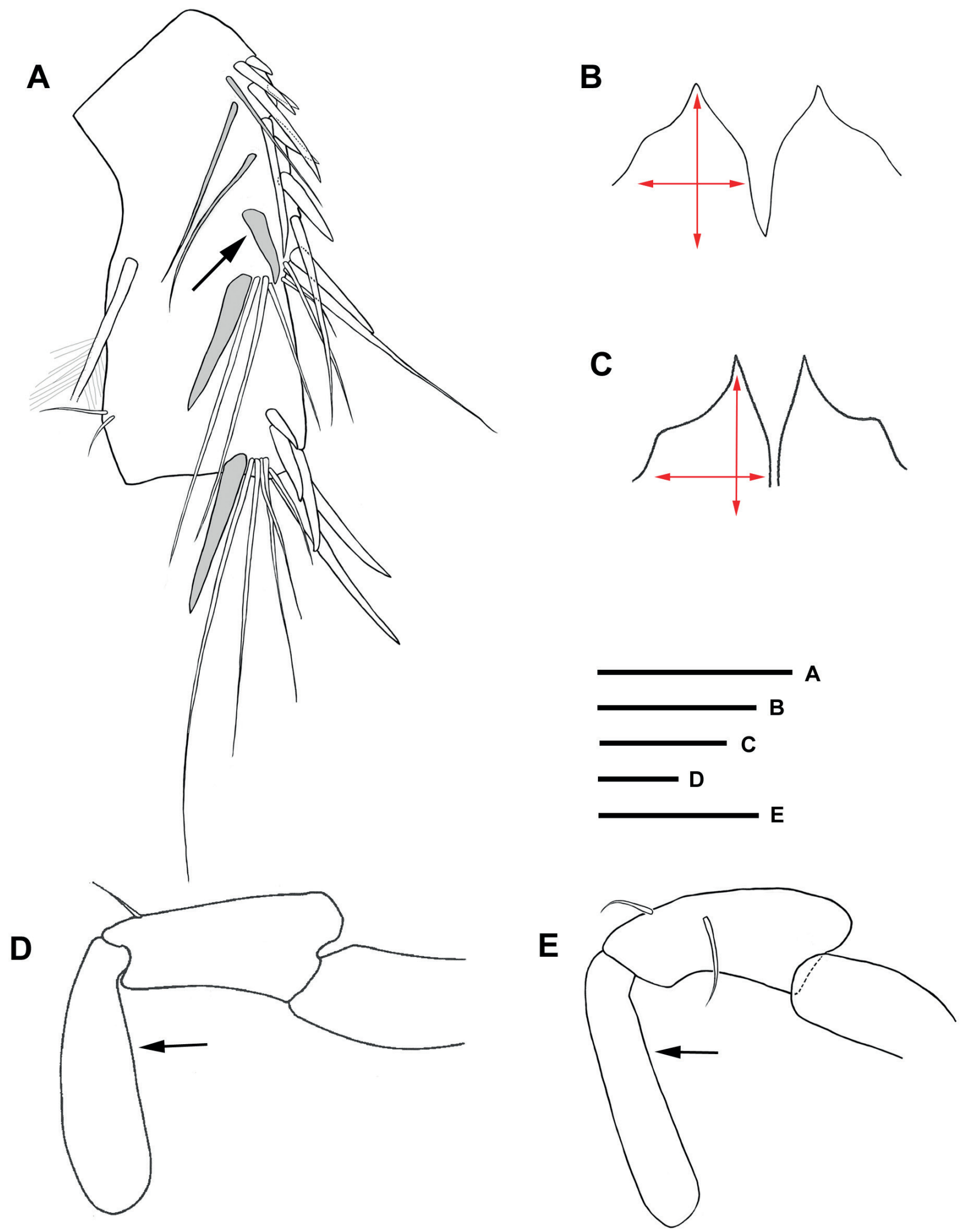

Figure 5. (A) Nebalia kocatasi female antenna, article 3, external side, lateral view. Lateral spine-like setae shaded, short proximal spine-like seta arrowed (setae of internal side omitted); (B) N. herbstii anal scales; (C) N. bipes anal scales (illustration from Dahl, 1985); (D) N. bipes mandibular palp, distal article arrowed (illustration from Dahl, 1985); (E) N. herstii mandibular palp, distal article arrowed. Scale bars: A, B, D, $0.2 \mathrm{~mm}$; C, $0.1 \mathrm{~mm}$; E, $0.5 \mathrm{~mm}$. 


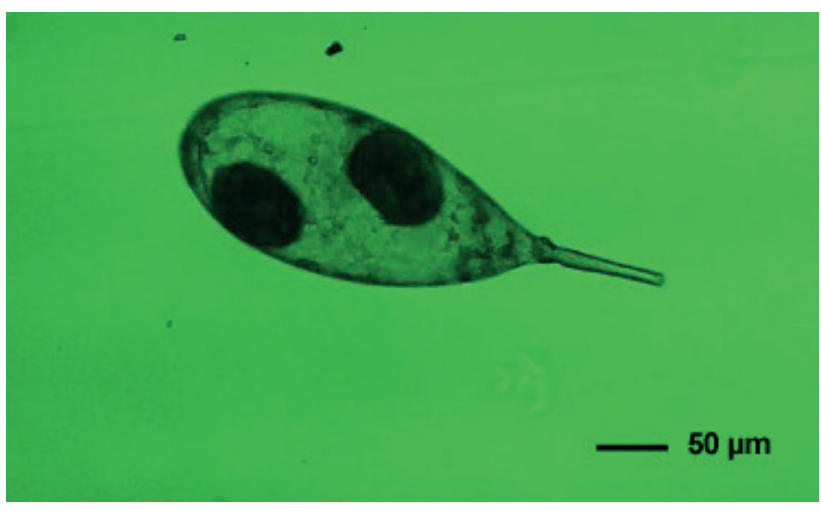

Figure 6. Unidentified epibiont detached from the carapace of Nebalia kocatasi sampled from Shetland Isles, 2003 (image courtesy of G. Fernandez-Leborans).

\section{ACKNOWLEDGEMENTS}

The authors would like to thank the following people for providing permission to use their specimens and data: Catherine McManus (Marine Harvest Ireland), Dr Anne-Marie Power, (National University of Ireland, Galway), Dr Andrew Bellamy (Tarmac Marine Ltd and Norwest Sand and Ballast Ltd), Mark Russell (British Marine Aggregate Producers Association), Paul McIlwaine (CEFAS; material from project C6794A funded by the Marine Management Organisation and projects C5787A and C5817 funded by DEFRA), Tim Mackie (DOENI), Ben Green (Natural England), Stuart Anderson (Anderson Marine Surveys), Ben Davies (Grisson Engineering Services Ltd), Farah Chaudry and Rachael Eyley (Gardline Environmental Ltd.), Fairfield Energy, Sheena Warnock (Scottish Sea Farms) and Dr Myles O'Reilly (SEPA). Specimens collected from Natura 2000 sites were funded by the Department of Agriculture, Food and the Marine and overseen by the Marine Institute to collect data in order to facilitate the Appropriate Assessment of Aquaculture and Fisheries activities. Dr Caroline Roche is thanked for help in preparation of the maps and Prof Gregorio Fernandez-Leborans is thanked for permission to reproduce the photograph presented in Fig. 6. Dr Juan Moreira is especially thanked for his assistance with identifications in particular his examination specimens of Nebalia kocatasi from Co. Cork, Co. Kerry, Co. Mayo and Co. Donegal and Nebalia strausi from Co. Cork and Co Mayo. The comments of two anonymous reviewers helped improve the manuscript.

\section{References}

Bowman, T.E.; Yager, J. and Iliffe, T.M. 1985. Speonebalia cannoni, n. gen., n. sp., from the Caicos Islands, the first hypogean leptostracan (Nebaliacea: Nebaliidae). Proceedings of the Biological Society of Washington, 98(2): 439-446.

Clark, A.E. 1932. Nebaliella caboti n. sp., with observations on other Nebaliacea. Transactions of the Royal Society of Canada, 26(5): 217-235.

Dahl, E. 1985. Crustacea Leptostraca, principles of taxonomy and a revision of European shelf species. Sarsia, 70(2-3): 135-165.

Fabricius, O. 1780. Fauna Groenlandica. Hafniae et Lipsiae, 452p.

Fahy, E. 1985. Feeding, Growth, and Parasites of Trout Salmo Trutta L. from Mulroy Bay, an Irish Sea Lough. Irish Fisheries Investigations Series A, No. 25, 1-12.

Fernandez-Leborans, G. 2001. A review of species of protozoan epibionts on crustaceans. III. Chonotrich Ciliates. Crustaceana, 74(6): 581-607.

Folk, R.L. 1954. The distinction between grain size and mineral composition in sedimentary-rock nomenclature. The Journal of Geology, 62(4): 344-359.

Hessler, R.R. 1984. Dahlella caldariensis, new genus, new species: a leptostracan (Crustacea, Malacostraca) from deep-sea hydrothermal vents. Journal of Crustacean Biology, 4(4): 655-664.

Hessler, R.R. and Sanders, H.L. 1965. Bathyal Leptostraca from the Continental Slope of the Northeastern United States. Crustaceana, 9(1): 71-74.

Koçak, C. and Katagan, T. 2006. A new record of Nebalia straus (sic) Risso, 1827 (Phyllocarida, Leptostraca) from the eastern Mediterranean. Crustaceana, 79(3): 319-325.

Koçak C. and Moreira, J. 2015. A new Nebalia species (Crustacea, Phyllocarida, Leptostraca) from the eastern Mediterranean Sea. Journal of the Marine Biological Association of the United Kingdom, 95(08): 1667-1675.

Koçak, C.; Moreira, J. and Katagan, T. 2007. First occurrence of Nebalia straus (sic) Risso, 1827 (Phyllocarida, Leptostraca) in the Levantine Basin (eastern Mediterranean). Crustaceana, 80(4): 447-453.

Koçak, C.; Moreira, J. and Katagan, T. 2010. New records of leptostracans (Crustacea, Phyllocarida) from the eastern Mediterranean. Turkish Journal of Zoology, 34(1): 69-77.

Koçak, C.; Moreira, J. and Katagan, T. 2011. New Records of the Genus Nebalia Leach, 1814 (Phyllocarida, Leptostraca) from the Mediterranean Coast of Turkey, with a Checklist of the Mediterranean Species of Leptostraca. Crustaceana, 84(4): 401-409.

Leach, W.E. 1814. The zoological miscellany, being descriptions of new and interesting animals. Vol. 3. London, E. Nodder, 149p.

Ledoyer, M. 1997. Leptostracés (Crustacea) de Méditerranée. Marine Life, 7(1-2): 29-38.

Ledoyer, M. 1998. Leptostracés (Crustacea) des côtes de Mauritanie récoltés au cours de la champagne Eumeli 4 
en 1992 et Sarsinebalia biscayensis n. sp. de la terrasse de Meriadzek, golfe de Gascogne (Nord-Est Atlantique). Marine Life, 8(1-2): 29-33.

Ledoyer, M. 2000. Leptostracés (Crustacea) de NouvelleCalédonie (mer de Corail, Ouest Pacifique). Marine Life, 10(1-2): 57-68.

Linder, F. 1943. Über Nebaliopsis typica G.O. Sars, nebst einigen allgemeinen Bemerkungen über die Leptostraken. Dana Reports, 4: 1-38.

Martínez, J.; Adarraga, I. and Ruiz, J.M. 2007. Tipificación de poblaciones bentónicas de los fondos blandos de la plataforma continental de Guipúzcoa (sureste del golfo de Vizcaya). Boletín del Instituto Español de Oceanografía, 23(1-4), 85-110.

Mauchline, J. 1984. Euphausiid, Stomatopod and Leptostracan crustaceans: keys and notes for the identification of the species. Synopsis of the British Fauna (New Series) 30. London, E.J. Brill \& W. Backhuys, 91p.

Mauchline, J. and Gage, J.D. 1983. The Nebaliacea (Crustacea: Leptostraca) of the Rockall Trough. Journal of the Marine Biological Association of the United Kingdom, 63(3): 627-631.

Moreira J.; Cacabelos, E. and Troncoso, J.S. 2009b. Primer registro de Nebalia kocatasi Moreira, Koçak et Katagan, 2007 (Crustacea, Phyllocarida, Leptostraca) en la Península Ibérica. Boletín de la Real Sociedad española de Historia Natural (Sección Biológica), 103(1-4): 65-72.

Moreira, J.; Díaz-Agras, G.; Candás, M.; Señarís, M.P. and Urgorri, V. 2009a. Leptostracans (Crustacea: Phyllocarida) from the Ría de Ferrol (Galicia, NW Iberian Peninsula), with description of a new species of Nebalia Leach, 1814. Scientia Marina, 73(2): 269-285.

Moreira J.; Gestoso, L. and Troncoso, J.S. 2003. Two new species of Sarsinebalia (Crustacea: Leptostraca) from Northeast Atlantic, with comments on the genus. Sarsia, 88(3): 189-209.

Moreira, J.; Koçak, C. and Katagan, T. 2007. Nebalia kocatasi sp. nov., a new species of leptostracan (Crustacea: Phyllocarida) from Izmir Bay (Aegan Sea, eastern Mediterranean). Journal of the Marine Biological Association of the United Kingdom, 87(5): 1247-1254.

Moreira, J.; Quintas, P. and Troncoso, J.S. 2004. Sobre la presencia de Nebalia strausi Risso, 1826 (Crustacea, Leptostraca) en la peninsula Ibérica. Boletín de la Real Sociedad Española de Historia Natural, 99(1-4): 83-92.

Olesen,J. 1999. A new species of Nebalia (Crustacea, Leptostraca) from Unguja Island (Zanzibar), Tanzania, East Africa, with a phylogenetic analysis of leptostracan genera. Journal of Natural History, 33(12): 1789-1809.
Olesen, J. and Walossek, D. 2000. Limb ontogeny and trunk segmentation in Nebalia species (Crustacea, Malacostraca, Leptostraca). Zoomorphology, 120: 47-64.

O’Reilly, M.; Hamilton, E. and Heaney, L. 2001. New records of Amphipods and Leptostracans from the Forth Sea Area, with notes on their copepod parasites (Siphonostomatoida: Nicothoidae). Glasgow Naturalist, 23(6): 35-42.

Risso, A. 1826. Histoire naturelle des principales productions de l'Europe méridionale et particulièrement de celles des environs de Nice et des Alpes Maritimes. Paris, Levrault, 5, 1-495.

Samouelle, G. 1819. The entomologist's useful compendium; or an introduction to the knowledge of British insects, comprising the best means of obtaining and preserving them, and a description of the apparatus generally used; together with the genera of Linné, and the modern method of arranging the classes Crustacea, Myriapoda, Spiders, Mites and insects, from their affinities and structure, according to the views of Dr. Leach. Also an explanation of the terms used in entomology; a calendar of the times of appearance and usual situations of near 3,000 species of British insects; with instructions for collecting and fitting up objects for the microscope. London, 496p.

Sars, G.O. 1870. Nye Dybvandscrustaceer fra Lofoten. Forhandlinger $i$ Videnskabs-Selskabet $i$ Christiana (1869): 147-174.

Sars, G.O. 1887. Report on the Phyllocarida collected by H.M.S. 'Challenger' during the years 1873-6. The Voyage of the H.M.S. 'Challenger', 19: 1-38.

Song, J.-H. and Min, G. S. 2016. A new species of Nebalia (Malacostraca: Phyllocarida: Leptostraca) from South Korea, with a key to the species of Nebalia Leach, 1814. Journal of the Marine Biological Association of the United Kingdom, doi: $10.1017 /$ S0025315415002180.

Tattersall, W.M. 1905. On Nebalia typhlops GO Sars. Report on the Sea and Inland Fisheries of Ireland, 1902-1903, 2: 210.

Tattersall, W.M. 1911. Part 41. Nebaliacea, Cumacea, Schizopoda, and Stomatopoda. In: Proceedings of the Royal Irish Academy. Section A: Mathematical and Physical Sciences, 41: 1-10.

Thiele, J. 1904. Die Leptostraken.-Wissenschaftliche Ergebnisse der DeutschenTiefsee-Expedition auf dem Dampfer "Valdiva," 1898-1899, 8: 1-a26.

Walker-Smith, G.K. 1998. A review of Nebaliella (Crustacea: Leptostraca) with the description of a new species from the continental slope of southeastern Australia. Memoirs of the Museum of Victoria, 57(1): 39-56.

Walker-Smith, G.K. and Poore, G.C. 2001. A phylogeny of the Leptostraca (Crustacea) with keys to families and genera. Memoirs of Museum Victoria, 58(2): 383-410. 